\title{
Утицај академских друштвених мрежа на видљивост научних радова истраживача
}

\author{
Данијела Арсенијевић \\ Универзитет у Новом Саду \\ Правни факултет у Новом Саду - Библиотека
}

darsenijevic@pf.uns.ac.rs

\begin{abstract}
Сажетак
Друштвене мреже савременог доба саставни су део свакодневног живота и рада људи, један од основних начина комуникације. Жеља за брзом разменом информација о научним достигнућима те потреба да за њиховом већом видљивости довела је до појаве друштвених академских мрежа. Како у свакодневном, тако и у сфери научног живота, комуникација на друштевним мрежама има своје позитивне и негативне аспекте. Губи се потреба за интеракцијом „лице у лице", али се остварује повезивање и сарадња истраживача, без обзира на место и време на коме се налазе, као и транспарентност и доступност научних резултата.

Ове могућности су основне карактеристике и покрета Отворена наука. Наука савременог доба зависи од видљивости доступности и могућности ширења резултата научних истраживања.

У овом раду начињен је покушај да се прикаже и анализира један број академских друштвених мрежа које су истраживачима на располагању, као и какав је њихов утицај на видљивост научних резултата у академској заједници.
\end{abstract}

Кључне речи: академске друштвене мреже, отворена наука, резултати научних истраживања, истраживачи, утицајност, видљивост

Увод

У експанзији научне продукције важи правило "publish or perish" - објави или пропадни. Притисак на истраживаче да објаве што већи број радова је довео до пораста броја објављених публикација и то таквог да се сваких 15 година њихов број двоструко повећава. ${ }^{1}$

Међутим, према неким истраживањима, један научни рад прочита тек 6 људи. ${ }^{2}$ Видљивост и утицајност истраживача зависи од више фактора, пре свега од утицајности публикације у којој је рад објављен, као и од њене доступности широј научној заједници. Може се рећи да цитираност неког научног рада више зависи од његове видљивости него од његовог квалитета. Отуда су истраживачи на неки начин приморани да објављују у релативно малом броју часописа у некој научној области који ће им донети бољу видљивост резултата рада. Ауторка овог рада је мишљења да су истраживачи приморани да раде на „личном маркетингу", односно на самопромоцији те да „присутност” може односити превагу над квалитетом.

Данас интернет, односно академске друштвене мреже (у даљем тексту: АДМ), омогућавају повезивање истраживача, прикупљање, размењивање и дељење научних информација, као и интензивирање комуникације међу научницима. Самим тим доводе до тога да њихов научни рад буде доступан и видљив већем кругу заинтересованих лица. Различита истраживања

\footnotetext{
1 Дамјан Крстајић, „Хиперпродукцијом радова до засићења у науци”, Research Centre for Cheminformatics, преузето 22.11 2018, http://www.rcc.org.rs/Objavljuj.pdf.

2 MCOnline Redakcija, "Internet platforme za naučnike i istraživače”, Media Centar Online, 27. 3. 2017, preuzeto 22. 11. 2018 https://www.media.ba/bs/magazin-mreze-i-web/internet-platforme-za-naucnike-i-istrazivace.
} 
показују да је овај начин приступа информацијама од суштинског значаја како за научна истраживања, тако и за развој научне каријере истраживача.

Присутност истраживача на АДМ, поред тога што пружа могућност брзе и једноставне научне комуникације, увелико утиче и на већу видљивост и утицајност његове научне продукције.

Имајући у виду све претходно речено, рад има за циљ да укаже на могућности повећања видљивости научноистраживачког рада коришћењем АДМ. Ово је урађено кроз три сегмента: довођење у везу савремених трендова у науци у виду Отворене науке и АДМ, приказ изабраних АДМ, њихових предности и недостатака, као и њихов утицај на научну продукцију и каријеру истраживача.

\section{Отворена наука и отворени приступ}

Отворена наука (eng. Open Science) подразумева слободан приступ научном знању, подацима и резултатима научних истраживања до којих су истраживачи дошли у свом раду. На тај начин се научни процес чини транспарентним и пружа могућности да наука постане доступнија, ангажованија и разумљивија свима. ${ }^{3}$ Овај приступ је увелико развијен у Европи, а сваког дана је све присутнији и у Републици Србији. У прилог томе говори и Платформа о отвореној науци коју је донело Министарство просвете, науке и технолошког развоја РС у јуну 2018. године, ${ }^{4}$ која се заснива на принципима отворене науке, а реализује се кроз отворен приступ научним публикацијама и примарним подацима.

Отворена наука (Open Science) је условљена отвореним приступом (Open Access). Он корисницима омогућава слободан и бесплатан приступ научним публикацијама на интернету (у пуном тексту), уз неограничену могућност дистрибуције и коришћења (читање, преузимање, чување, штампање), са обавезом навођења тачног извора информација. Такође подразумева и постављање научних публикација у дигиталне репозиторијуме ${ }^{5}$ (институционалне или тематске), односно електронске часописе са отвореним приступом.

У зависности од корисничких права, постоји неколико модела отвореног приступа. Модели о којима се најчешће говори су зелени (Green Road) и златни (Golden Road). Зелени отворени приступ подразумева постављање научног дела у дигитални репозиторијум са слободним приступом уз дозволу издавача (на којег је аутор пренео ауторска права), док златни подразумева објављивање научног дела у часописима или књигама који су бесплатно доступни преко интернета, а трошкове припреме за објављивање сносе аутори или установе.

\section{Дигитални извори отвореног приступа:}

- ROAR ${ }^{6}$ (Registry of Open Access Repositories) обухвата архиве отвореног приступа које је могуће претраживати по географској регији или типу садржаја (тезе, часописи, базе података);

- OpenDOAR ${ }^{7}$ је директоријум који окупља преко 2900 академских репозиторијума у Open Access режиму, из целог света;

\footnotetext{
${ }^{3}$ Снежана Смедеревац и др., Ошиворена наука: ирракса и иерсиеекиииве (Нови Сад: Универзитет у Новом Саду, 2020$), 8$.

${ }^{4}$ Министарство просвете, науке и технолошког развоја Републике Србије, Плаш̄форма за ойворену науку, преузето 19. 11. 2018, http://www.mpn.gov.rs/wp-content/uploads/2018/07/Platforma-za-otvorenu-nauku.pdf.

${ }^{5}$ Дигитални репозиторијуми су организоване збирке различитих докумената (књига, чланака у часописима, слика и др.) у дигиталном облику. Документи су или оригинално настали у дигиталном облику (born digital) или су накнадно дигитализовани. - Универзитетска библиотека "Светозар Марковић”, „Шта су дигитални репозиторијуми“, преузето 9. 12. 2020, https://unilib.libguides. com/c.php?g=660498\&p=4664241

${ }^{6}$ Registry of Open Access Repositories, preuzeto 17. 11. 2018, http://roar.eprints.org/.

7 OpenDOAR, preuzeto 17. 11. 2018, http://www.opendoar.org/.
} 
- DOAJ ${ }^{8}$ (Directory of Open Access Journals) је сервис који обухвата преко 15.000 часописа из 134 земаља. У њему су заступљени и српски научни часописи са метаподацима ${ }^{9}$ радова и линком до пуног текста;

- The European Library ${ }^{10}$ (TEL) обезбеђује директан приступ до око 160 милиона проверених извора из 48 европских националних библиотека. У оквиру портала могу се пронаћи не само текстуални, већ и велики број мултимедијалних садржаја;

- DART Europe ${ }^{11}$ је дигитални репозиторијум дисертација одбрањених на преко 600 универзитета из 28 земаља Европе;

- $\mathbf{D O A B}^{12}$ (Directory of Open Access Books). На њему су доступни линкови ка пуним текстовима за преко 32.000 књига из свих области науке.

Дигитални репозиторијуми у Србији:

- doiSerbia ${ }^{13}$ (садржи 66 наслова домаћих научних часописа), који одржава Центар за научне информације Народне библиотеке Србије;

- CRIS UNS ${ }^{14}$ (информациони систем научне делатности Универзитета у Новом Саду који садржи дигиталну библиотеку докторских дисертација одбрањених на Универзитету у Новом Саду);

- Дигитални репозиторијуми Универзитета у Београду ${ }^{15}$, Нишу ${ }^{16}$ и Крагујевцу ${ }^{17}$ (системи за дугорочно похрањивање, индексирање и коришћење дигиталних објеката. Они омогућавају да се резултати рада њихових истраживача систематски архивирају, трајно чувају и учине приступачним светској јавности);

- NaRDUS ${ }^{18}$ (заједнички портал свих докторских дисертација и извештаја комисија о њиховој оцени, на универзитетима у Србији).

Важност покрета Отворене науке и отвореног приступа науци препознаје се и у академским друштвеним мрежама које имају важан утицај за научну комуникацију у 21. веку. ${ }^{19}$

\section{Академске друштвене мреже}

У наставку ће бити представљено неколико АДМ које истраживачи најчешће користе. Којим ће се мрежама истраживач придружити, зависи од могућности које оне нуде, а које задовољавају њихове потребе или очекивања. Оно што условљава избор свакако јесу и ограничења које мреже постављају својим корисницима.

\footnotetext{
${ }^{8}$ DOAJ (Directory of Open Access Journals), preuzeto 17. 11. 2018, https://doaj.org/.

9 Метаподаци су структуриране информације које описују, објашњавају, лоцирају или на други начин чине лакшим проналажење, коришћење или управљање неким извором информација. Често се дефинишу као подаци о подацима или информације о информацијама. - Гејл Хоџ, „Метаподаци на лак начин: водич за библиотеке“ 1 (2004): 157, преузето 11. 10. 2018, http://www.nb.rs/view_file.php?file_id=860.

10 The European Library, Last update 2020, preuzeto 17. 10. 2020, http://www.theeuropeanlibrary.org/tel4/.

11 DART-Europe E-theses Portal, preuzeto 17. 10. 2020, http://www.dart-europe.eu/basic-search.php.

12 Directory of Open Access Books, preuzeto 17. 10. 2020, https://www.doabooks.org/.

13 doiSerbia, poslednja promena 19. 10. 2020, preuzeto 20. 10 2020, http://www.doiserbia.nb.rs/.

${ }^{14}$ CRIS UNS (Current Research Information System University of Novi Sad), preuzeto 20. 11. 2018, https://www.cris.uns.ac.rs/index.jsf.

15 PHAIDRA - Дигитални репозиторијум Универзитета у Београду, преузето 20. 11. 2018, https://phaidrabg.bg.ac.rs/

16 PHAIDRA - Дигитални репозиторијум Универзитета у Нишу, преузето 20. 11. 2018, https://phaidrani.ni.ac.rs/.

17 PHAIDRA - Дигитални репозиторијум Универзитета у Крагујевцу, преузето 20. 11. 2018, https://phaidrakg.kg.ac.rs/.

18 NaRDuS - Национални Репозиторијум Дисертација у Србији, преузето 18. 10. 2020, http://nardus.mpn.gov.rs/.

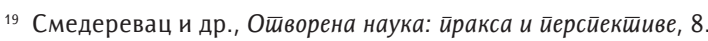


Једна од првих друштвених академских мрежа која се појавила је Academia.edu. ${ }^{20}$ Основао ју је Ричард Прајс 2008. године и представља најмасовнију друштвену мрежу за истраживаче. На Academia.edu тренутно је пријављено преко 139 милиона академаца који су поставили 39 милиона радова.

На овој АДМ омогућено је постављање научних радова и истраживања, праћење и аналитика њиховог утицаја и њихово преузимање. Корисници могу да креирају сопствене странице, објављују информације везане за своја научна интересовања, постављају линкове до пуних текстова радова које су објавили, прате активности појединих колега, њихову продукцију и сл. Профилна страница омогућава увид у то колико корисника прати активности одређеног истраживача.

Опција, специфична само за ову мрежу, нуди могућност истраживачима да, користећи функцију Sessions, дискутују са колегама о рукопису/истраживању у трајању од 20 дана. На тај начин добијају корисне повратне информације о свом раду, пре него што га пошаљу на објављивање.

Недостатак ове мреже представља то што је затвореног типа и не функционише у потпуности са принципом отвореног приступа. Да би се приступило материјалу који је у отвореном приступу, истраживач се мора регистровати, односно направити кориснички налог, који је, додуше, бесплатан. За приступање материјалима који нису у отвореном приступу плаћа се одређена новчана надокнада на годишњем нивоу. Такође, аутори који желе да њихови радови буду препоручени другим истраживачима морају за то да плате одређену надокнаду. Ово наводи на закључак да комерцијални приступ, односно жеља за стицањем профита, и даље има велику предност у односу на добробит коју доноси отворен приступ научним садржајима и слободно ширење научног знања.

ResearchGate 21 је осмислио немачки вирусолог др Ијад Мадиш 2008. године. У току рада на експерименту из радиологије, била му је потребна размена искустава и мишљења са колегама из других научних области, која би му умногоме олакшала рад. Дошао је на идеју да направи друштвену мрежу за научнике и тако је настао ResearchGate. Као и Academia.edu и ова мрежа је намењена брзој и једноставној размени научних информација и научних радова. Мото ове мреже гласи: „Откријте научна сазнања и учините истраживање видљивим“.22

ResearchGate по начину функционисања веома подсећа на најпопуларнију друштвену мрежу Facebook. ${ }^{23}$ Корисник може да креира свој професионални профил и уређује га по свом избору, у смислу информација о својим интересовањима, образовању, искуствима, контакту и још много тога. Постоји могућност додавања контаката, праћења корисника истих интересовања и њихових активности, приказивања хронологије објављених садржаја итд. Притом корисник увек има потпуну контролу над видљивошћу података и информација које пружа на свом профилу.

Оно што је за истраживаче важно, ова мрежа нуди функцију дискусионих форума (корисници могу да формирају групе у којима раде заједно у интерактивном окружењу, размењујући савете и искуства). Омогућено је праћење статистичких података о броју прегледа радова истраживача, преузимања, цитата у оквиру система. С обзиром на то да подржава ОАІ-PMH протокол, ${ }^{24}$ други системи могу да преузимају податке о постављеним радовима. ResearchGate

\footnotetext{
20 Academia, preuzeto 17. 10. 2020, https://www.academia.edu/.

21 ResearchGate, preuzeto 1. 10. 2020, https://www.researchgate.net/

22 ResearchGate, „Discover scientific knowledge, and make your research visible”, preuzeto 1. 10. 2020, https://www.researchgate.net/.

23 Facebook - једна од најпопуларнијих бесплатних друштвених или социјалних мрежа која представља онлајн веб-сервис који корисницима омогућава разноврсне видове комуникације и могућност личне презентације. - Слађана Крстић, „Шта су друштвене мреже?", ATEC Technologies, преузето18. 1. 2018, https://atec.rs/sta-su-drustvene-mreze/.

${ }^{24}$ OAI-PMH (Open Archive Initiative - Protocol for Metadata Harvesting) је протокол, односно међународни стандард интероперабилности архива и репозиторијума заснован на прикупљању, обради и размени метаподатака. - Универзитет у Крагујевцу, Рецник шеремина везаних за ошиворену науку, преузето 14. 10. 2020, https://www.kg.ac.rs/otvorenost_nauke_VIII.php?pismo=latinica.
} 
користи семантичко претраживање (истовремено се анализира шири низ појмова у односу на стандардне методе претраге), што даје прецизније резултате. Ова претрага се врши у оквиру сопствених интерних ресурса, као и у спољним научноистраживачким базама података.

На свом профилу истраживач може поставити рад у пуном тексту, или навести само референцу, а да рад шаље колегама на њихов захтев. Истраживачи могу да повежу своја обавештења и најновије вести са разним другим мрежама или платформама за блоговање, као што су LinkedIn i Twitter, како би дошли до што шире публике.

Ипак, ResearchGate-u се замера то што се „споро креће“. По мишљењу појединих истраживача, протекло време од тражења до добијања информације је сувише дуго. Такође, постоје мишљења да је мање „пријатељског“, а више корпоративног окружења те да je ResearchGate пре свега профитна организација. Још једна замерка овој мрежи је та да се не бави довољно ауторским правима.

Google Scholar ${ }^{25}$ се појавио 2004. године и заправо није АДМ, већ претраживач који индексира научне радове истраживача у пуном тексту који су доступни на интернету. То могу бити рецензирани радови, чланци у часописима, књиге, сажеци, као и други материјали који представљају резултате научног рада. Као и претходни, и овај сервис омогућава креирање профила корисника. Једном креиран, он се може аутоматски ажурирати чланцима који припадају профилу сходно подацима који су унети. Google Scholar даје статистичке податке о броју цитата и Х-индексу, ${ }^{26}$ тако да се може сматрати некомерцијалном цитатном базом. Уколико истраживач има креиран профил на Google Scholar-y, његово рангирање у Google претрази ће бити боље. То је препознато као одличан начин за повећане видљивости не само истраживача, већ и институција. ${ }^{27}$ У Google Scholar-y не постоји могућност депоновања научних радова у пуном тексту. Међутим, уколико је рад јавно доступан на интернету, он ће га у већини случајева регистровати, што значи да ће поред наслова стајати линк до пуног текста рада.

Mendeley 28 је програм за управљање библиографским референцама и академска друштвена мрежа. Дизајниран је за истраживаче, студенте и научнике и служи за проналажење, чување, организовање и управљање библиографским подацима, односно литературом, који су коришћени током процеса истраживачког рада и стварања научног дела.

Mendeley је бесплатан програм који кориснику, након регистровања, пружа могућност да креира своју личну библиотеку у којој може да чува не само библиографске референце, већ и саме радове. Своју библиотеку може да претражује преко кључних речи (по наслову, аутору, публикацији). Текст на коме ради може да анотира (означава, прави белешке). Постоје опције избора различитих цитатних стилова које Mendeley подржава, укључујући оне популарне као што су АПА, Харвард, Чикаго, АМА и Ванкувер, који се најчешће примењују у научним часописима. Могућа је размена радова и формирања група које могу бити јавне (прикључује се свако ко жели), по позиву (прикључују се они којима се упути позив) и приватне.

У бесплатној верзији, Mendeley на свом порталу нуди 2GB простора за личну библиотеку и могућност креирања једне приватне групе са до три корисника. Свом налогу се може приступити са различитих уређаја (РС рачунара, таблета, телефона) и сви уређаји могу да се синхронизују. Поред бесплатне верзије, могућа је надоградња уз плаћање која обезбеђује више простора за чување, већу видљивост у друштвеним академским мрежама итд.

\footnotetext{
25 Google Scholar, preuzeto 1. 10. 2020, https://scholar.google.com/

${ }^{26} \mathrm{X}$-индекс је показатељ научне успешности истраживача који се израчунава на основу броја објављених радова и њихове цитираности у радовима других истраживача.

27 Примера ради, Ректорски колегијум Универзитета Црне Горе је у фебруару 2018. године донео препоруку да академско особље направи свој Google Scholar профил као „допринос подизању видљивости Универзитета на ранг листама, а такође и својој личној видљивости као научника и истраживача". - Ректорат, „Google Scholar профили", Универзитет Црне Горе, последња промена 27. 5. 2020, преузето 17. 10. 2020, https://www.ucg.ac.me/objava/blog/1029/objava/79266-google-scholar-profili.

${ }_{28}$ Mendeley, preuzeto 1. 10. 2020, https://www.mendeley.com/?interaction_required=true
} 
Преузимање података и попуњавање библиотеке је једноставно, као и само цитирање и израда библиографије. Подаци се могу преузимати преко онлајн база података (нпр: Google Scholar, PDF документи доступни у пуном тексту, онлајн библиотечких каталога), преузимањем података из других програма за управљање референцама који су компатибилни са Mendeley-ем или ручно. Подаци библиотеке се чувају на серверу портала и доступни су само регистрованом кориснику. ${ }^{29}$

Својим корисницима нуди веома добру техничку подршку и даје кратка и јасна упутства на свом YouTube каналу.

Mendeley је од 2013. године у власништву компаније Elsevier. Ово је изазвало критике једног дела научне јавности који се залаже за отворени приступ, с обзиром да се ради о једној од најпрофитабилнијих издавачких кућа (првенствено научних часописа) са огромним годишњим приходом. ${ }^{30}$ Високе цене претплата на научне часописе компаније Elsevier су изазвале велико незадовољство шире научне заједнице и учиниле је једним од најконтроверзнијих издавача научне литературе.

У мноштву података и информација који се могу наћи на друштвеним мрежама и интернету уопште, честе су грешке које се појављују у препознавању тачног имена и презимена аутора. Оне се најчешће јављају због недоследности самих аутора у навођењу имена (дијакритички знаци vs. „ошишана латиница"31; дј уместо ђ; додавање средњег слова; иницијали уместо пуног имена и презимена). До забуне и непрепознавања истраживача може доћи и због промене презимена, промене или недоследног навођења афилијације, као и због бројних других разлога техничке природе. 3бог тога се појавила потреба за стварањем сервиса који ће направити јединствени систем за идентификацију истраживача. Сервис ORCID ${ }^{32}$ је покренут у новембру 2012. године, управо да би се могућности грешака свеле на минимум. Овај сервис омогућава истраживачу да бесплатно креира и уређује профил у који уноси своје личне податке, области научног интересовања, кључне речи, списак објављених научних радова, афилијацију итд. Он потом добија ORCID broj (Open Researcher and Contributor ID) који представља јединствени и трајни идентификатор истраживача формиран у виду алфанумеричког кода. С обзиром на то да ORCID број омогућава размену података широког круга информационих система, његово коришћење истраживачима омогућује бољу видљивост.

Поред академских друштвених мрежа, истраживачи се повезују и путем других пословних и социјалних друштвених мрежа. Најпопуларније међу њима су свакако LinkedIn (пословна друштвена мрежа која повезује професионалце свих профила а не само научнике) и социјални медији Facebook, Twitter, Instagram... Неки истраживачи их сматрају идеалним медијима за проширене научне разговоре и брзе дискусије о најновијим темама. Наравно, има и оних који доживљавају традиционалне друштвене мреже као непрофесионалне платформе које би могле да компромитују и угрозе године озбиљног истраживачког рада. ${ }^{33}$

У не тако давној прошлости, комуникација између истраживача и размена њихових научних резултата је била ограничена искључиво на лични контакт, учешће на конференцијама, праћење научне литературе у штампаном облику, што је у великој мери било условљено финансијским могућностима (одласци у иностранство на научне скупове, скупе претплате на научне часописе...). Исто тако, поједини традиционални начини научне комуникације

\footnotetext{
29 Ана Чорић Самарџија, Основе раяа с алаш̄има за уйрављање референиама: Word, Zotero, Mendeley: D 500 (Загреб: Свеучилишни рачунски центар, 2017), преузето 10. 10. 2018, https://www.srce.unizg.hr/files/srce/docs/edu/osnovni-tecajevi/d501_polaznik. pdf

${ }^{30}$ Биљана Косановић, „Национална платформа отворене науке - нови задаци и изазови“ (рад представљен на Конференцији Дани отворене науке, Београд, Србија, 18-19. октобар 2018).

31 Ошишана латиница - латинична слова без дијакритичких знакова (č-c, š-s, ć-c, ž-z)

32 ORCID, Last update 17. 10. 2020, preuzeto 18. 10 2020, https://orcid.org/

33 Laura Van Eperen and Francesco M. Marincola, "How scientists use social media to communicate their research". Journal of Translational Medicine, No. 9 (2011): 199, preuzeto 19. 10. 2018, doi:10.1186/1479-5876-9-199.
} 
подразумевају презентације научних резултата без повратне информације (рад се излаже на конференцији или објављује у штампаној научној публикацији, а аутор врло ретко добије повратну информацију).

Данас је у академској заједници јасно изражена потреба да научни радови буду доступни што већем броју читалаца јер то директно утиче на видљивост и утицајност радова, а што је опет уско повезано са напредовањем у каријери истраживача. Присуство на АДМ управо то омогућава јер олакшава комуникацију истраживача из различитих делова света, међусобно повезивање и сарадњу на нивоу појединаца или групе. Ова научна кореспонденција условљена је коришћењем неких од светских језика и писама. Истраживања показују да радови објављени на енглеском језику имају већу цитираност. ${ }^{34}$

Такође, могућност активног учешћа колега из истих или сродних научних области у свим фазама стварања научног рада је од велике користи.

Иако су предности постојања АДМ велике, оне са собом носе и одређена спорна питања. Пре свега се мисли на кршење ауторских права, о чему би истраживачи требало да воде рачуна и добро се упознају са тиме шта смеју (легално) да постављају на својим профила на АДМ. ${ }^{35}$ Аутори који желе да поставе своје радове у пуном тексту морају претходно да се упознају са политиком издавача јер од момента предаје рада ауторска права се преносе издавачима. Већина комерцијалних издавача не дозвољава да се чланци у часописима за које се плаћа претплата стављају у отворен приступ, било на профилу аутора у АДМ или репозиторијумима.

Поставља се питање да ли се на резултат научног рада може гледати као на нешто што припада људској заједници, што представља опште добро и какав је однос између тих општих добара, комерцијалних интереса издавача и самих истраживача. Тренутно, комерцијални приступ смањује видљивост резултата научних радова. Може деловати наивно, али потребно је размислити о томе да ли постоји решење које свим учесницима научне комуникације доноси добробит.

У појединим областима љуског стваралаштва, нарочито у области уметности (музика, филм), аутори се свесно одричу ауторских права постављајући своја дела на друштвене мреже или интернет странице уз слободан приступ садржајима. Извор прихода са продаје ауторских права помера се на приходе од оглашивача који се рекламирају на тим мрежама и страницама. Оваква пракса може да послужи као инспирација комерцијалним издавачима за отворенији приступ научним радовима.

На крају, остају два кључна питања квалитета и контроле садржаја који се постављају на АДМ. У контексту наметнуте хиперпродукције научноистраживачких резултата, ради бржег напредовања у каријери, могућа је појава неетичког понашања истраживача у виду постављања неквалитетних или плагираних радова на својим профилима. Последице одсуства контроле и постојања садржаја таквог квалитета могу изазвати различите реакције научне заједнице. Далекосежније су последице на развој научне мисли и кредибилитет њених носилаца. Иако, ови случајеви нису карактеристични искључиво за АДМ, већ се јављају и у штампаним публикацијама.

Да ли се са АДМ решава проблем невидљивости или се ствара нови проблем - видљивост, али без контроле? Можда је одговор у констатацији Аудуна Фарбута да ће научници својим знањем и способносима зарадити поверење колега и научне заједнице, али ће га оправдати само применом основних вредности академског интегритета. ${ }^{36}$

\footnotetext{
${ }^{34}$ Mario S. Di Bitetti and Julian A. Ferreras, "Publish (in English) or perish: The effect on citation rate of using languages other than English in scientific publications", Ambio No. 46 (2017): 121, preuzeto 18. 10. 2020, doi: 10.1007/s13280-016-0820-7.

35 Више о томе: Милица Шевкушић, „Шта смете да поставите на друштвене мреже”, Секција библиотекара и књижничара, Институт техничких наука САНУ, преузето 18.10. 2020, http://www.itn.sanu.ac.rs/sekcija/index.php/sta-smete-da-postavite-na -drustvene-mreze-za-naucnike.

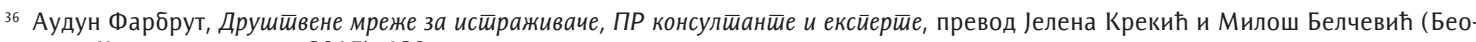
град: Ковачница прича, 2017), 128.
} 


\section{Закључак}

Формирање академских друштвених мрежа је допринело стварању и успостављању база истраживача и њихових научних сазнања. Оне, са једне стране, помажу истраживачима у стварању научних радова кроз доступност и размену литературе и научних достигнућа, док им са друге стране омогућавају пласирање научних резултата широј научној заједници, а да притом не морају бити формално објављени. Све је чешћа појава да су поједине публикације доступне једино у електронском облику и то на АДМ. Један од основних разлога зашто се истраживачи придружују АДМ је могућност приступа чланцима у часописима за које се иначе плаћа претплата издавачима.

Иако део научне јавности још увек сматра да је постојање, односно учешће друштвених мрежа у науци сувишно, да има истраживача који су несклони оваквом начину ширења и дистрибуције научних сазнања, требало би узети у обзир озбиљност и важност овог феномена савременог доба.

Друштвене академске мреже су несумњиво веома снажан алат који истраживачи могу да искористе за повећање своје видљивости а самим тим и утицајности. Они који се одлуче да креирају налог на некој од АДМ не би требало да остану пасивни посматрачи, већ да активно доприносе размени научних информација и свој налог редовно ажурирају.

\section{Литература и извори:}

1. Academia. Preuzeto 17. 10. 2020. https://www.academia.edu/

2. Čorić Samardžija, Ana. Osnove rada s alatima za upravljanje referencama: Word, Zotero, Mendeley: D 500. Zagreb: Sveučilišni računski centar, 2017. Preuzeto 10. 10. 2018. https://www.srce.unizg.hr/files/srce/ docs/edu/osnovni-tecajevi/d501_polaznik.pdf

3. CRIS UNS (Current Research Information System University of Novi Sad). Preuzeto 17. 10. 2020. https://www.cris.uns.ac.rs/index.jsf.

4. DART-Europe E-theses Portal. Preuzeto 17. 10. 2020. http://www.dart-europe.eu/basic-search.php.

5. Di Bitetti, Mario S. and Ferreras, Julia'n A. "Publish (in English) or perish: The effect on citation rate of using languages other than English in scientific publications". Ambio No. 46 (2017): 121-127. Preuzeto 18. 10. 2020. doi: 10.1007/s13280-016-0820-7

6. Directory of Open Access Books. Preuzeto 17. 10. 2020. https://www.doabooks.org/.

7. DOAJ (Directory of Open Access Journals). Preuzeto 17. 11. 2018. https://doaj.org/.

8. doiSerbia. Ažurirano 19. 10. 2020, preuzeto 20. 10 2020. http://www.doiserbia.nb.rs/.

9. Farbrut, Audun. Društvene mreže za istraživače, PR konsultante i eksperte. Prevod Jelena Krekić i Miloš Belčević. Beograd: Kovačnica priča, 2017.

10. Google Scholar, Preuzeto 1. 10. 2020. https://scholar.google.com/.

11. Hodž, Gejl. "Metapodaci na lak način: vodič za biblioteke“. Glasnik Narodne biblioteke Srbije Godina VI, br. 1 (2004): 157-180. Preuzeto 11.10. 2018. http://www.nb.rs/view_file.php?file_id=860.

12. Kosanović, Biljana. „Nacionalna platforma otvorene nauke - novi zadaci i izazovi“. Rad predstavljen na Konferenciji „Dani otvorene nauke“, Beograd, Srbija, 18-19. oktobar 2018.

13. Krstajić, Damjan. „Hiperprodukcijom radova do zasićenja u nauci”. Research Centre for Cheminformatics. Preuzeto 22. 11. 2018. http://www.rcc.org.rs/Objavljuj.pdf.

14. Krstić, Slađana. „Šta su društvene mreže?”. ATEC Technologies. Preuzeto18. 1. 2018. https://atec.rs/ sta-su-drustvene-mreze/.

15. MCOnline Redakcija. „Internet platforme za naučnike i istraživače”. Media Centar Online, 27. 3. 2017. Preuzeto 22. 11. 2018. https://www.media.ba/bs/magazin-mreze-i-web/internet-platforme-za-naucnike-i-istrazivace. 16. Mendeley. Preuzeto 1.10.2020. https://www.mendeley.com/?interaction_required=true. 
17. Ministarstvo prosvete, nauke i tehnološkog razvoja Republike Srbije. Platforma za otvorenu nauku. Preuzeto 19. 11. 2018, http://www.mpn.gov.rs/wp-content/uploads/2018/07/Platforma-za-otvorenu-nauku.pdf.

18. NaRDuS - Nacionalni Repozitorijum Disertacija u Srbiji. Preuzeto 18. 10. 2020. http://nardus.mpn.gov.rs/. 19. OpenDOAR. Preuzeto 17. 11. 2018. http://www.opendoar.org/.

20. ORCID. Last update 17. 10. 2020, preuzeto 18. 10. 2020, https://orcid.org/.

21. PHAIDRA - Digitalni repozitorijum Univerziteta u Beogradu. Preuzeto 20. 11. 2018. https://phaidrabg. bg.ac.rs/.

22. PHAIDRA - Digitalni repozitorijum Univerziteta u Kragujevcu. Preuzeto 20. 11. 2018. https://phaidrakg. kg.ac.rs/.

23. PHAIDRA - Digitalni repozitorijum Univerziteta u Nišu. Preuzeto 20. 11. 2018. https://phaidrani.ni.ac.rs/.

24. Registry of Open Access Repositories. Preuzeto 17. 11. 2018. http://roar.eprints.org/.

25. Rektorat. "Google Scholar profili”. Univerzitet Crne Gore. Ažurirano 27. 5. 2020, preuzeto 17. 10. 2020, https://www.ucg.ac.me/objava/blog/1029/objava/79266-google-scholar-profili.

26. ResearchGate. Preuzeto 1. 10. 2020. https://www.researchgate.net/

27. Ševkušić, Milica. „Šta smete da postavite na društvene mreže”. Sekcija bibliotekara i knjižničara. Institut tehničkih nauka SANU. Preuzeto 18. 10. 2020. http://www.itn.sanu.ac.rs/sekcija/index.php/ sta-smete-da-postavite-na-drustvene-mreze-za-naucnike.

28. Smederevac, Snežana, Dejan Pajić, Sanja Radovanović, Silvia Ghilezan, Petar Čolović i Branko Milosavljević. Otvorena nauka: praksa i perspektive. Novi Sad: Univerzitet u Novom Sadu, 2020.

29. The European Library. Last update 2020, preuzeto 17. 10. 2020, http://www.theeuropeanlibrary.org/tel4/.

30. Univerzitet u Kragujevcu. Rečnik termina vezanih za otvorenu nauku. Preuzeto 14. 10. 2020. https://www. kg.ac.rs/otvorenost_nauke_VIII.php?pismo=latinica.

31. Univerzitetska biblioteka "Svetozar Marković". „Šta su digitalni repozitorijumi“. Preuzeto 9. 12. 2020. https://unilib.libguides.com/c.php?g=660498\&p=4664241.

32. Van Eperen, Laura and Francesco M. Marincola. "How scientists use social media to communicate their research". Journal of Translational Medicine, No. 9 (2011): 199. Preuzeto 19. 10. 2018. doi:10.1186/1479-5876-9-199

\title{
Influence of Academic Social Networks on the Visibility of Scientific Research Papers
}

\begin{abstract}
Summary
Social networks are an integral part of everyday life and work of modern people and one of the basic ways of communication and exchange of information among them. The desire for a quick exchange of information regarding scientific achievements and the need for their greater visibility have led to the emergence of social academic networks. Communication on social networks has its positive and negative aspects in both everyday and scientific lives. The need for face-to-face interaction is lost, but the connection and cooperation of researchers can be achieved regardless of place and time. Transparency and availability of scientific results are also provided. These possibilities are the basic characteristics of the Open Science movement. The science of the modern age depends on the visibility, accessibility and possibility of disseminating the results of scientific research. In this paper, an attempt has been made to present a number of academic social networks available to researchers, as well as to analyze their impact on the visibility of scientific results in the academic community.
\end{abstract}

Keywords: academic social networks, open science, results of scientific research, researchers, influence, visibility 


\section{అ৫:ச}

Утицај академских друштвених мрежа на видљивост научних радова истраживача bу Данијела Арсенијевић is licensed under a Creative Commons Attribution-NonCommercial-NoDerivatives 4.0 International License. 